\title{
Keefektifan Metode Cooperative Learning Tipe STAD untuk Pendidikan Karakter melalui Pembelajaran IPS
}

\author{
ROSO SUGIYANTO \\ Fakultas Keguruan dan Ilmu Pendidikan, Universitas Palangkaraya \\ e-mail : rososugiyanto@gmail.com
}

\begin{abstract}
Abstrak
Penelitian ini bertujuan untuk: 1) Mengetahui perbedaan keefektifan metode pembelajaran Cooperative Learning tipe STAD dan metode pembelajaran konvensional untuk hasil belajar IPS; 2) Mengetahui perbedaan keefektifan metode Cooperative Learning tipe STAD dan metode pembelajaran konvensional untuk pendidikan karakter nilai kejujuran siswa. Desain eksperimen yang digunakan adalah pretest-posttes control group design. Populasi penelitian ini adalah semua siswa kelas VIII SMP Negeri 4 Depok dengan teknik random sampling melalui tes dan non-tes. Teknik analisis dengan statistik parametrik yaitu uji-t. Hasil penelitian menunjukkan: 1) Metode Cooperative learning tipe STAD lebih efektif untuk meningkatan hasil belajar IPS dibandingkan metode pembelajaran konvensional (t-hitung sebesar 5,610 dengan $\mathrm{p}=0,000<0,05$ ), 2) Metode Cooperative learning tipe $S T A D$ lebih efektif untuk pendidikan karakter nilai kejujuran dibandingkan dengan metode pembelajaran konvensional (t-hitung sebesar 10,209 dengan $\mathrm{p}=0.000 \mathrm{p}<0.05$ ). Kata kunci: Metode Cooperative learning tipe STAD, hasil belajar, kejujuran.
\end{abstract}

\begin{abstract}
This study aims to: 1) determine difference in the effectiveness of STAD cooperative learning and conventional instructional methods in Social Studies; 2 ) know the difference in the effectiveness of STAD cooperative learning and conventional instructional methods for character education of student's honesty. This research is a quasi-experimental. The experimental design used was a pretest - post tes controlled group design. The population in this study was all eighth grade students of SMP Negeri 4 Depok Sleman. The sample was selected by random sampling technique to determine the experimental class and the control class. The data was obtained from a test to measure the learning outcomes of Social Studies learning and non-test or a questionnaire with Likert scale to obtain data about honesty. The data analysis technique used is the statistical analysis of parametric t-test. The results of this study indicate that: 1 ) STAD Cooperative learning method proved to be effective for improving the learning outcomes of Social Sciences instructional compared with conventional instructional method ( $t$-test was 5. 610 with $p=0.000<0.05$ ), 2 ) STAD Cooperative learning method was proven to be more effective for character education especially honesty compared with conventional instructional method ( $t$-score of 10,209 with $p=0.000 p<0.05$ ).
\end{abstract}

Keywords: STAD cooperative learning, learning outcomes, honesty. 


\section{PENDAHULUAN}

Salah satu masalah yang tengah dihadapi oleh bangsa Indonesia adalah sistem pendidikan dini yang ada sekarang ini terlalu berorientasi pada pengembangan otak kiri (kognitif) dan kurang memperhatikan pengembangan otak kanan (afektif, empati, dan rasa). Padahal, pengembangan karakter lebih berkaitan dengan optimalisasi fungsi otak kanan. Mata pelajaran yang berkaitan dengan pendidikan karakter pun (seperti budi pekerti dan agama) ternyata pada prakteknya lebih menekankan pada aspek otak kiri (hafalan, atau hanya sekedar "tahu"). Padahal, pembentukan karakter harus dilakukan secara sistematis dan berkesinambungan yang melibatkan aspek "knowledge, feeling, and acting" (Lickona, 1991: 51).

Karakter bangsa merupakan aspek penting dari kualitas sumber daya manusia karena kualitas karakter bangsa menentukan kemajuan suatu bangsa. Karakter yang berkualitas perlu dibentuk dan dibina sejak usia dini. Usia dini merupakan masa penentuan bagi pembentukan karakter seseorang. Kegagalan penanaman kepribadian yang baik di usia dini ini akan membentuk pribadi yang bermasalah di masa dewasanya kelak.

Berdasarkan observasi awal yang dilakukan peneliti sebelum pelaksanaan penelitian, bahwa kondisi pembelajaran di SMP Negeri 4 Depok antara lain seperti suasana belajar di kelas masih bersifat kompetitif atau persaingan. Hal ini terlihat dari prilaku siswa yang individualis, yaitu siswa tidak peduli dengan temannya apakah mengalami kesulitan belajar atau tidak yang penting diriya sudah menguasai materi yang disampaikan oleh gurunya. Dalam melaksanakan pembelajaran umumnya guru masih mengunakan metode secara asal. Penggunaan metode secara asal ini tidak berdasarkan pada analisis kesesuaian antara isi pelajaran dengan kinerja (performansi) yang menjadi sasaran pembelajaran. Padahal keefektifan suatu metode pembelajaran sangat ditentukan oleh kesesuaian antara isi dengan performansi (Etin Solehatin dan Raharjo 2007: 2).

Berdasarkan hasil wawancara dengan be- berapa guru mata pelajaran bahwa salah satu yang dihadapi oleh guru di sekolah dalam mewujudkan pembelajaran yang efektif guru berhadapan dengan materi yang memiliki cakupan yang luas, hal ini dapat menyulitkan guru untuk menstruktur dan mensintesiskan materi pelajaran secara cermat sesuai de ngan sasaran belajar. Tugas ini memerlukan pengetahuan yang cukup tentang perencanaan pembelajaran. Sejauh ini guru juga belum memahami kompleksitas bidang studi yang diajarkannya dalam hubungannya de ngan bidang studi yang lain, sehingga pengintegrasian nilai-nilai karakter dalam pelajaran menjadi kurang efekif.

Masalah lain adalah terkait pengintegrasian nilai-nilai karakter dalam pembelajaran belum terlaksana maksimal. Hal ini disebabkan karena pengintegrasian nilai-nilai karak ter dilakukan hanya terbatas pada mata pelajaran tertentu saja. Proses pembelajaran yang terjadi masih fokus pada ranah kognitif siswa saja. Dalam proses pembelajaran guru terpaku pada text book, sehingga penggunaan sumber belajar kurang bervariasi dan pembelajaran yang terjadi kurang menyentuh pengalaman dan kebutuhan siswa seharihari sehingga pembelajaran IPS kurang me narik perhatian siswa.

Salah satu metode yang dapat digunakan oleh guru untuk mengatasi permasalahan tersebut adalah penggunaan metode pembelajaran kooperatif. Pembelajaran kooperatif adalah khas diantara metode-metode pembelajaran yang ada karena menggunakan struktur tugas dengan penghargaan yang bebeda untuk meningkatkan pembelajaran siswa. Struktur tugas memaksa siswa untuk bekerjasama dalam kelompok kecil. Sistem penghargaan mengakui usaha bersama, sama baiknya seperti usaha individual. Pembelajaran kooperatif merupakan perwujudan dari pembelajaran konstruktivisme yang akan mampu meningkatkan prestasi belajar siswa dan mendidik siswa menjadi siswa yang berkarakter terpuji. Hal ini karena siswa diberi kesempatan agar menggunakan strateginya sendiri, dalam belajar secara sadar, sedangkan guru membimbing siswa ke tingkat pengetahuan yang lebih tinggi. Dengan kata 
lain pembelajaran kooperatif adalah kegiatan saling bertukar gagasan atau pikiran dalam kelompok kerjanya dan bertanggung jawab pada dirinya sendiri.

Berdasarkan latar belakang di atas, maka sangatlah penting bagi institusi pendidikan untuk mengembangan metode pembelajaran yang dapat secara efektif digunakan dalam pencapaian pendidikan karakter yang terintegrasi dalam bidang mata pelajaran. Untuk itu sangat penting dilakukan penelitian untuk menentukan efektif tidaknya suatu metode pembelajaran, hal ini metode cooperative learning tipe STAD untuk pendidikan karakter melalui pembelajaran IPS di tingkat SMP.

Salah satu tipe pembelajaran kooperatif yaitu Student Team Achievement Division (STAD) merupakan tipe pembelajaran kooperatif yang mempunyai keunggulan untuk memberikan pemahaman konsep materi yang sulit kepada siswa di mana materi pembelajaran dipersiapkan oleh guru dalam lembar kerja atau perangkat pembelajaran yang lain. Selain itu pembelajaran kooperatif tipe STAD lebih sederhana dibandingkan dengan pembelajaran kooperatif tipe yang lain dan bagus untuk guru yang baru memulai pembelajaran menggunakan pendekatan kooperatif. Slavin (1995: 71) :

"STAD is one of the simplest of all cooperative learning methods, and is a good model to begin with for teachers who are new to the cooperative approach".

STAD terdiri atas lima tahap pembelajaran, yaitu: Penyajian Materi, kegiatan kelompok, pelaksanaan kuis individual, nilai perkembangan individu, penghargaan kelompok. Sampai saat ini metode pembelajaran kooperatif belum banyak diterapkan dalam pelaksanaan proses pembelajaran IPS dikarenakan kebanyakan pelajar atau guru enggan untuk menerapkan sistem ini karena beberapa alasan yakni, menurut Slavin (Soewarso, 1998: 16-25) mengatakan ada nya beberapa masalah dalam menerapkan strategi belajar bersama di kelas yaitu ramai, gagal untuk saling mengenal, perilaku yang salah dan penggunaan waktu yang kurang efektif. Namun demikian, menurut Soewarso,
(1998: 16-25) pembelajaran kooperatif tipe STAD juga memiliki keuntungan yakni:

1. Membantu siswa mempelajari isi materi pelajaran yang sedang dibahas.

2. Adanya anggota kelompok lain yang menghindari kemungkinan siswa mendapatkan nilai rendah, karena dalam pengetesan lisan siswa dibantu oleh anggota kelompoknya.

3. Menjadikan siswa mampu belajar berdebat, belajar mendengarkan pendapat orang lain, dan mencatat hal-hal yang bermanfaat untuk kepentingan bersama.

4. Menghasilkan pencapaian belajar siswa yang tinggi serta menambah harga diri siswa dan memperbaiki hubungan de ngan teman sebaya.

5. Hadiah atau penghargaan yang diberikan akan memberikan dorongan bagi siswa untuk mencapai hasil yang lebih tinggi.

6. Siswa yang lambat berpikir dapat dibantu untuk menambah ilmu pengetahuannya.

7. Pembentukan kelompok-kelompok kecil memudahkan guru untuk memonitor siswa dalam belajar bekerja sama.

National Council for Social Studies (NSCC)

Ilmu Pengetahuan Sosial didefinisikan seba gai berikut:

Social studies as "the integrated study of the social sciences and humanities to promote civic competence. "Within the school program, social studies provides coordinated, systemic study drawing upon such disciplines as anthropology, archeology, economics, geography, law, philosophy, political science, psychology, religion and sociology, as well as appropriate content from the humanities, mathematic and natural sciences (Savage, 1996: 9).

Dari pengertian di atas dapat diartikan bahwa: 1) Ilmu Pengetahuan Sosial sebagai studi integrasi dari ilmu-ilmu sosial dalam kemanusiaan untuk meningkatkan kemampuan warganya, dalam lingkup program sekolah, 2) Ilmu Pengetahuan Sosial diberikan dengan studi yang terkoordinasi dan sistematis yang dibangun atas dasar disiplin-disiplin ilmu antropologi, arkeologi, ekonomi, geografi, hukum, filsafat, ilmu politik, psikologi, agama dan sosiologi maupun 
isi terapan dari humaniora, matematika dan ilmu murni.

Isjoni (2007: 50-51) berpendapat bahwa ada empat tujuan pembelajaran IPS yaitu; a) knowledge yang merupakan tujuan utama dari pengetahuan sosial yaitu membentuk para siswa belajar tentang diri mereka sendiri dan lingkungannya; b) skill yaitu kemampuan menggunakan dan mengamalkan pengatahuan dan ide-ide melalui ketrampilan berfikir; c) attitudes dikelompokkan dua yaitu kelompok sikap yang diperlukan untuk tingkah laku berfikir (intellectual behavior) dan tingkah laku sosial (social behavior); d) values yaitu nilai yang terkandung di dalam masyarakat yang didapatkan dari lingkungan masyarakat. Keempat tujuan tersebut akan bermuara pada tujuan utama IPS yaitu untuk melatih siswa untuk bertanggung jawab se bagai warga Negara yang baik.

Nilai yang akan dikaji dalam penelitian ini adalah nilai pada tataran moral, yakni nilai yang dekat dengan wilayah nilai etika (baikburuk). Nilai moral ini memiliki kualitas baik buruk yang sudah dimanifestasikan dalam tindakan sebagai alat kebiasaan seseorang. Watak atau karakter seseorang dibentuk oleh nilai-nilai yang dipilihnya, diusahakan, dan secara konsisten diwujudkan dalam tindakan.

Terkait dengan metode pembelajaran yang akan diterapkan melalui pendekatan cooperative learning, nilai-nilai yang dapat dikembangkan pada siswa untuk jenjang SMP/MTS seperti yang telah ditetapkan oleh Puskur Kemendiknas (Said Hamid Hasan, dkk, 2010: 9-10) adalah sebagai berikut: Nilai religius, jujur, toleransi, disiplin, kerja keras, kreatif, mandiri, demokratis, rasa ingin tahu, semangat kebangsaan, cinta tanah air, menghargai prestasi, bersahabat/komunikatif, cinta damai, gemar membaca, peduli lingkungan, peduli sosial, tanggung-jawab.

Dari beberapa nilai-nilai yang dijelaskan seperti di atas, maka penelitian ini difokuskan pada penanaman nilai kejujuran melalui pembelajaran IPS. Nilai kejujuran tersebut menjadi fokus dalam penelitian ini atas dasar nilai kejujuran merupakan nilai yang paling penting dan mendasari perwujudan nilai- nilai karakter yang lainnya. Dengan diinternalisasinya nilai kejujuran diharapkan siswa meyakini dan melaksanakan ajaran Tuhan yang maha esa, mampu mengikuti pelajaran, bekerja kelompok atau individu (mengerjakan tugas belajar) dengan disiplin dan dapat mempertanggungjawabkan hasilnya dan mampu mengedepankan nilai-nilai ka rakter yang baik.

Menurut Marzuki, (2009:165-167) Sikap jujur dapat dilihat dari berbagai bentuk, ya itu:

1. Benar dalam perkataan. Siswa harus selalu berkata benar dalam keadaan apa pun dan bagaimana pun.

2. Benar dalam berjanji. Siswa selalu menepati janji ketika ia berjanji, dengan siapa pun janji itu dibuat.

3. Benar dalam pergaulan. Siwa tidak hanya cukup benar dalam perkataannya, tetapi juga benar dalam pergaulannya, setiap siswa dilarang menipu, bohong, khianat, dan yag sejenisnya.

4. Benar dalam kemauan. Dengan bekal kejujuran, siswa akan dapat menuruti kemauannya yang benar.

5. Benar dalam kenyataan. Siswa menampilkan apa yang sesungguhnya terjadi pada dirinya dan tidak membohongi orang lain di sekitarnya.

Perilaku jujur perlu mendapat apresiasi dan penghargaan yang tinggi serta pujian yang tulus pada setiap anak yang melakukannya. Dalam pelaksanaannya anak perlu diberi pemahaman dan penjelasan tentang arti dan manfaat kejujuran dalam kehidupan bersama. Dari penjelasan di atas dapat disimpulkan bahwa nilai kejujuran adalah mengakui kesalahan, berbicara dan bertindak sesuai dengan kenyataan, tidak mengambil hak milik orang lain tanpa ijin, dan berbuat sesuai dengan kenyataan/kemampuan sendiri.

Sekolah adalah tempat yang tepat untuk menanamkan tonggak pilar-pilar karakter, karena pada usia ini anak sudah mulai berfikir secara moral dan mulai berkembang penalaran moralnya. Agar pendidikan karakter berhasil menanamkan nilai-nilai yang dise pakati oleh komunitas, dalam hal ini lembaga 
pendidikan, maka metode yang digunakan harus tepat, yaitu pendidikan yang menyeluruh (integral) dan komprehensif. Salah satu cara yang digunakan adalah dengan mengintegrasaikan pendidikan karakter dengan kurikulum sekolah. Artinya perangkat kurikulum per-mata pelajaran harus mengintegrasikan pendidikan karakter di dalamnya.

Salah satu mata pelajaran yang dapat diintegrasi dengan pendidikan karakter adalah pelajaran IPS. Pembelajaran IPS bertolak atas dasar realitas dan fenomena sosial yang mewujudkan satu pendekatan interdisipli ner dari aspek dan cabang-cabang ilmu-ilmu sosial. Siswa perlu dibekali dengan nilai-nilai karakter yang berlaku dalam masyarakat agar dapat menyikapi realitas dan fenomena sosial yang terjadi dalam masyarakat. Penanaman nilai-nilai karakter sebagai bagian dari pendidikan karakter merupakan bagian dari domain prilaku.

Untuk itu diperlukan suatu metode pembelajaran IPS yang secara efektif dapat merangsang siswa untuk berfikir, bekerja, dan bersikap rasional dengan pengalaman belajar secara langsung di sekolah. Dalam penelitian ini, metode pembelajaran yang akan diujikan adalah Coperative Lerning tipe STAD yang merupakan metode pembelajaran yang secara sadar dan sistematis mengembangkan interaksi yang silih asah (saling mencerdaskan), silih asih (saling menyaya ngi), dan silih asuh (saling tenggang rasa) antar sesama siswa sebagai latihan hidup dari dalam masyarakat nyata.

Pemilihan tipe STAD dalam tulisan ini karena pembelajaran kooperatif tipe STAD dapat digunakan untuk memberikan pemahaman konsep materi yang sulit kepada siswa dimana materi tersebut telah dipersiapkan oleh guru melalui lembar kerja atau perangkat pembelajaran yang lain. Selain itu pembelajaran kooperatif tipe STAD lebih sederhana dibandingkan dengan pembelajaran kooperatif tipe yang lain dan bagus untuk guru yang baru memulai pembelajaran menggunakan pendekatan kooperatif.

Sedangkan domain yang akan diteliti meliputi pengetahuan IPS dan domain prilaku terkait nilai karakter yaitu nilai kejujuran. Ke- berhasilan metode pembelajaran ini dalam pencapaian domain prilaku merupakan bagian yang tidak terpisahkan dari keberhasilan pembelajaran IPS itu sendiri.

\section{METODE}

Penelitian ini merupakan quasi-experimental research. Quasi eksperimen merupa kan sebuah eksperimen semu dalam sebuah penelitian karena melibatkan penggunaan kelompok subjek utuh dalam eksperimen yang secara alami sudah terbentuk. Diguna kan penelitian quasi eksperimen ini karena dalam bidang pendidikan, seringkali sulit melakukan eksperimen secara murni. Dalam hal ini, karena subjek (peserta didik) adalah bukanlah suatu yang dapat dipindah, diperlakukan, dan diatur secara tepat sebagai mana pada penelitian eksperimen murni. Dalam penelitian ini ada dua kelompok, yaitu kelompok eksperimen dan kelompok kontrol. Pada kelompok eksperimen diberikan perlakuan tertentu yaitu dalam proses pembelajarannya menggunakan metode Cooperative learning tipe $S T A D$, sedangkan pada kelas kontrol diberikan perlakuan seperti biasanya yaitu dalam proses pembelajarannya dengan menggunaakan metode belajar secara konvensional.

Populasi dalam penelitian ini adalah siswa kelas VIII SMP Negeri 4 Depok Yogyakarta yang terbagi dalam 4 kelas. Sampel dalam penelitian ini diambil melalui teknik random sampling, yaitu teknik pengambilan sampel secara acak. Penentuan kelas eksperimen dan kelas kontrol ditentukan secara random. Random dilakukan dengan cara mengundi kelas-kelas yang akan dijadikan sebagai subjek penelitian, kelompok pertama dipilih sebagai kelompok eksperimen dan kelompok kedua sebagai kelompok kontrol. Dari jumlah populasi yang keseluruhan terba gi dalam 4 kelas, dirandom dan terpilih dua kelas yang akan dijadikan sampel penelitian. Kelas VIII C dengan jumlah siswa 27 orang terpilih sebagai kelompok eksperimen dan kelas VIII D dengan jumlah siswa 27 orang terpilih sebagai kelompok kontrol.

Secara garis besar, teknik pengumpulan 
data dalam penelitian ini meliputi pertama mengadakan pretest, kedua memberikan perlakuan berupa pemberian pembelajaran IPS dengan menggunakan metode pembelajaran Cooperative Learning tipe STAD dan menggunakan metode secara konvensional, ketiga memberikan post-test. Hasil dari posttest ini sebagai data yang akan dianalisis untuk kemudian ditarik kesimpulan penelitian. Metode yang digunakan dalam pengumpulan data adalah dengan tes (tes hasil belajar) dan non tes (angket, pengamatan/ observasi, dan wawancara).

\section{HASIL DAN PEMBAHASAN}

1. Deskripsi Data Pre-Test Kelompok Eksperimen dan Kelompok Kontrol

Pengambilan data pre-test dilaksanakan pada awal penelitian sebelum kelompok diberi perlakuan atau sebelum eksperimen berlangsung. Jumlah keseluruhan siswa yang mengikuti pre-test adalah 54 siswa dengan rincian sebanyak 27 siswa kelas VIII C dan 27 siswa kelas VIII D SMP Negeri 4 Depok, Sleman.

a. Deskripsi Data Pre-Test Kelompok Eksperimen

\section{1) Hasil Belajar IPS}

Berdasarkan hasil statistik deskriptif dengan menggunakan SPSS 16 for Windows, menunjukan bahwa skor rata-rata hasil belajar IPS siswa kelompok eksperimen yaitu 54,96, standar deviasi 7,852, dengan Skor tertinggi yaitu 68 dan skor terendah yaitu 30 .

Berdasarkan kategorisasi memperlihatkan bahwa kemampuan awal subjek penelitian dalam belajar IPS yang sangat tinggi sebesar 11,11\% atau sebanyak 3 siswa, yang termasuk dalam kategori tinggi sebesar $40,74 \%$ atau sebanyak 11 siswa, yang termasuk dalam kategori rendah sebesar 40,74\% atau sebanyak 11 siswa, dan yang termasuk dalam kategori sangat rendah sebesar 7,41\% atau sebanyak 2 siswa. Hasil tersebut menunjukan bahwa secara umum kemampuan awal siswa dalam belajar IPS dalam kategori sedang-sedang saja atau tidak terlalu tinggi maupun terlalu rendah akan tetapi seimbang antara tinggi dan rendah.

Untuk lebih jelasnya, kemampuan awal subjek dalam belajar IPS digambarkan dalam histogram berikut ini.

Gambar 1.

Histogram Kategorisasi Skor Pre-test Hasil Belajar IPS Kelompok Eksperimen

\section{HASIL BELAJAR IPS}

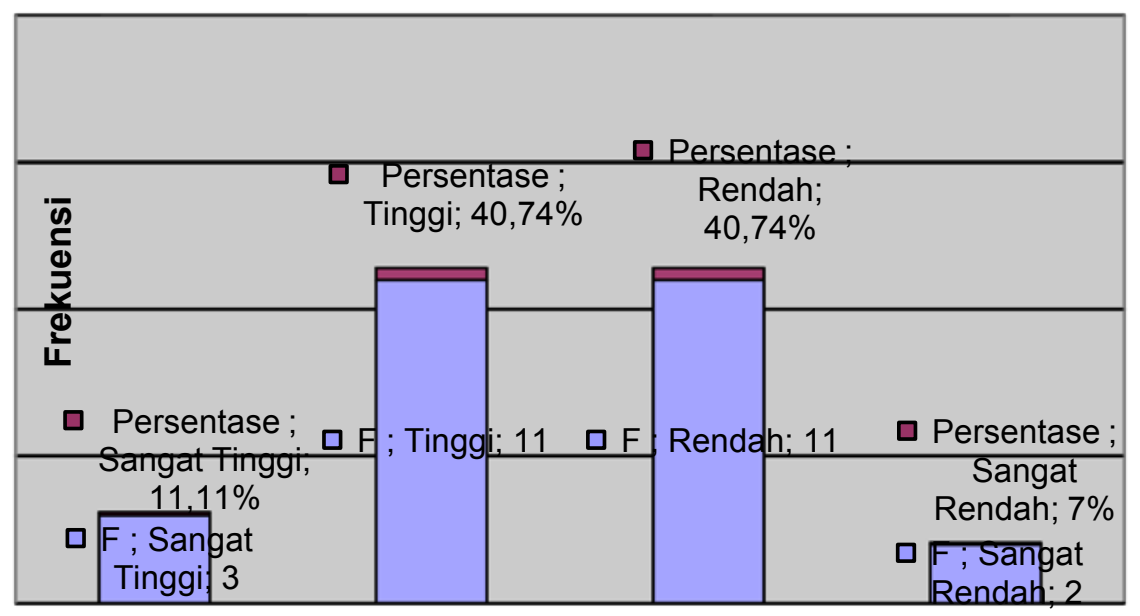

Kategori 
2) Nilai Kejujuran

Berdasarkan hasil statistik deskriptif dengan menggunakan SPSS 16 for Windows, menunjukan bahwa skor rata-rata kejujuran siswa kelompok eksperimen yaitu 83,63, standar deviasi 4,869, dengan skor tertinggi yaitu 93 dan skor terendah yaitu 70 .

Berdasarkan kategorisasi memperlihatkan bahwa tingkat kejujuran subjek penelitian yang sangat tinggi sebesar $14,81 \%$ atau sebanyak 4 siswa, yang termasuk dalam kate gori tinggi sebesar 29,63\% atau sebanyak 8 siswa, yang termasuk dalam kategori rendah sebesar $44,44 \%$ atau sebanyak 12 siswa, dan yang termasuk dalam kategori sangat rendah sebesar $11,11 \%$ atau sebanyak 3 siswa.

Untuk lebih jelasnya, tingkat kejujuran subjek digambarkan dalam histogram berikut ini.

Gambar 2.

Histogram Kategorisasi Tingkat Kejujuran Kelompok Eksperimen

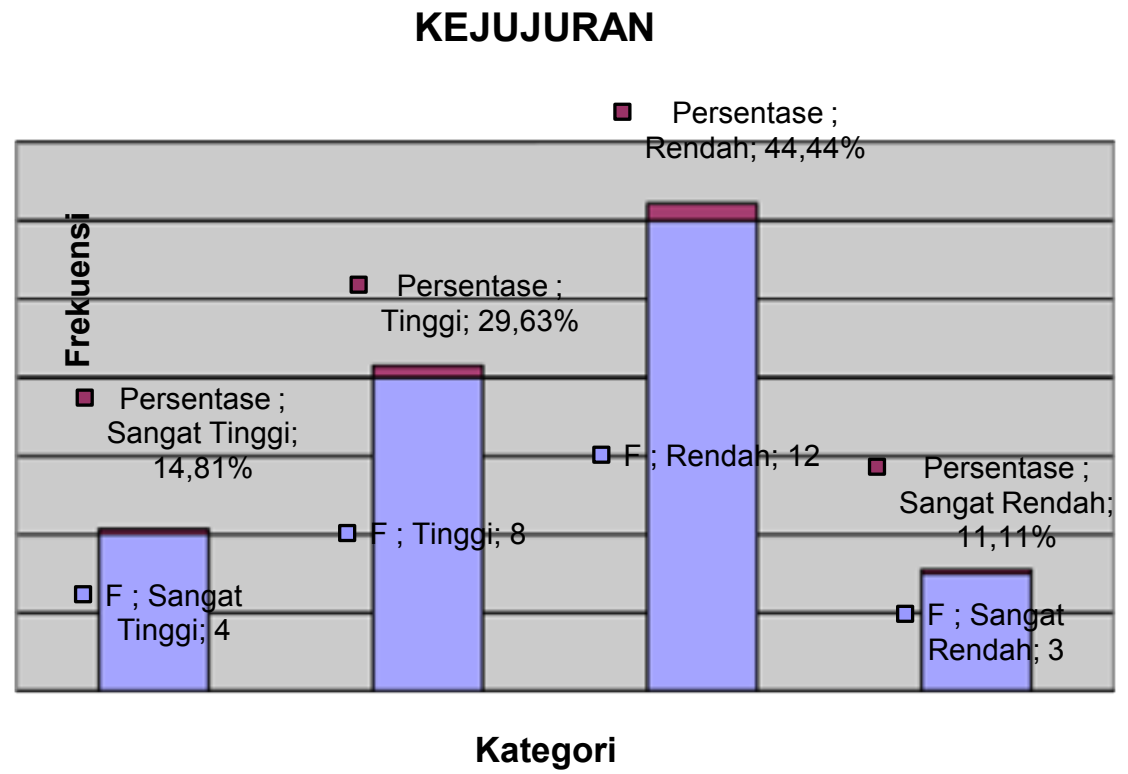

b. Deskripsi Data Pre-Test Kelompok Kontrol

1) Hasil Belajar IPS

Berdasarkan hasil statistik deskriptif dengan menggunakan SPSS 16 for Windows, menunjukan bahwa skor rata-rata hasil belajar IPS siswa kelompok kontrol yaitu 56,67, standar deviasi 7,442, dengan skor tertinggi yaitu 68 dan skor terendah yaitu 46 .

Berdasarkan kategorisasi memperlihatkan bahwa kemampuan awal subjek penelitian dalam belajar IPS yang sangat tinggi sebesar $29,23 \%$ atau sebanyak 8 siswa, yang termasuk dalam kategori tinggi sebesar $11,11 \%$ atau sebanyak 3 siswa, yang termasuk dalam kategori rendah sebesar 40,74\% atau sebanyak 11 siswa, dan yang termasuk dalam kategori sangat rendah sebesar 18,52\% atau sebanyak 5 siswa. Hasil tersebut menunjukan bahwa secara umum kemampuan awal subjek penelitian dalam belajar IPS termasuk dalam kategori rendah dan sebagian termasuk kategori sangat tinggi.

Untuk lebih jelasnya, kemampuan awal subjek penelitian dalam belajar IPS digambarkan dalam histogram berikut ini. 
Gambar 3.

Histogram Kategorisasi Skor Pre-test Hasil Belajar IPS Kelompok Kontrol

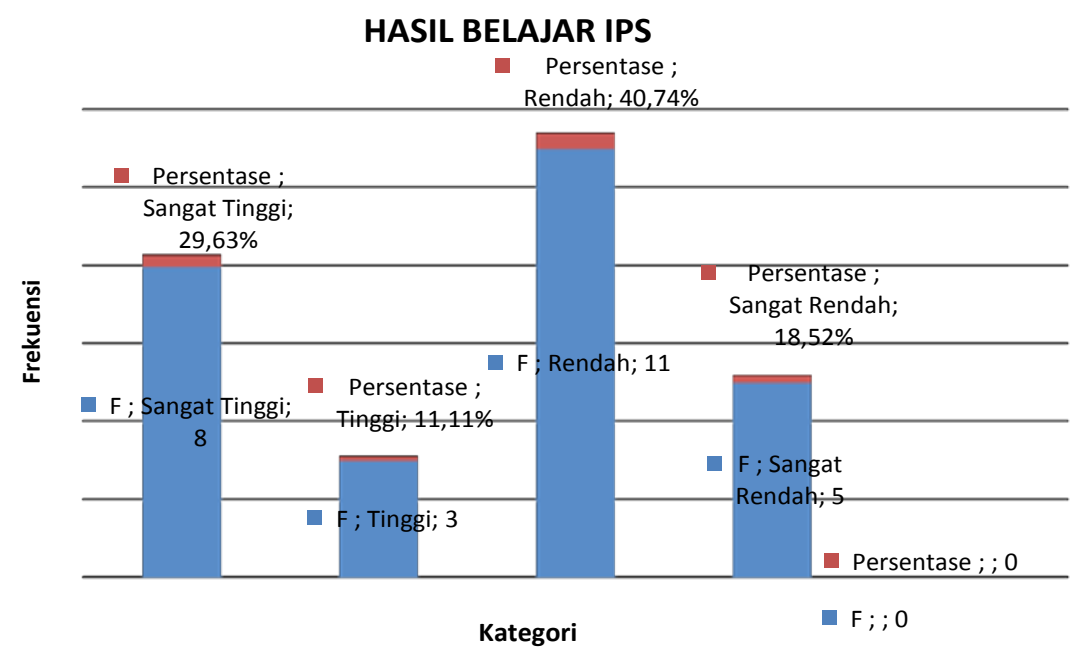

2) Nilai Kejujuran

Berdasarkan hasil statistik deskriptif dengan menggunakan SPSS 16 for Windows, menunjukan bahwa skor rata-rata kejujuran siswa kelompok kontrol yaitu 85,63, standar deviasi 5,930, dengan skor tertinggi yaitu 95 dan skor terendah yaitu 70 .

Berdasarkan kategorisasi memperlihatkan bahwa tingkat kejujuran subjek yang sangat tinggi sebesar $14,81 \%$ atau sebanyak 4 siswa, yang termasuk dalam kategori tinggi sebesar 29,63\% atau sebanyak 8 siswa, yang termasuk dalam kategori rendah sebesar $33,33 \%$ atau sebanyak 9 siswa, dan yang termasuk dalam kategori sangat rendah sebesar $22,22 \%$ atau sebanyak 6 siswa. Hasil tersebut menunjukan bahwa secara umum tingkat kejujuran subjek penelitian termasuk dalam kategori antara tinggi dengan rendah.

Untuk lebih jelasnya, tingkat kejujuran subjek digambarkan dalam histogram berikut ini.

\section{Gambar 4 \\ Histogram Kategorisasi Tingkat Kejujuran Kelompok Kontrol}

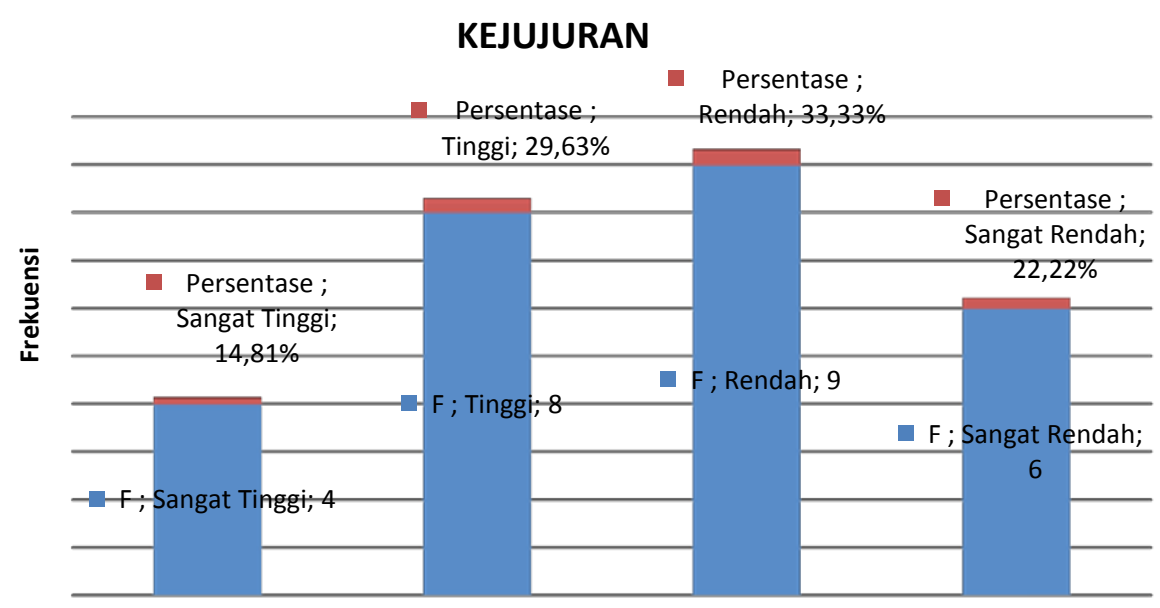

Kategori 


\section{Deskripsi Data Post-test Kelas Eksper- imen dan Kelas Kontrol}

1) Hasil Belajar IPS

Berdasarkan hasil statistik deskriptif dengan menggunakan SPSS 16 for Windows, menunjukan bahwa skor rata-rata hasil belajar IPS subjek penelitian kelompok eksperimen yaitu 70,37, standar deviasi 4,609, de ngan Skor tertinggi yaitu 84 dan skor terendah yaitu 60. Berdasarkan kategorisasi memperlihatkan bahwa kemampuan akhir subjek dalam belajar IPS yang termasuk dalam kate gori sangat tinggi sebesar 7,41\% atau seba nyak 2 siswa, yang termasuk dalam kategori tinggi sebesar 59,26\% atau sebanyak 16 siswa, yang termasuk dalam kategori rendah sebesar 22,22\% atau sebanyak 6 siswa, dan yang termasuk dalam kategori sangat rendah sebesar 11,11\% atau sebanyak 3 siswa. Hasil tersebut menunjukan bahwa secara umum kemampuan akhir siswa dalam belajar IPS termasuk dalam kategori tinggi.

Untuk lebih jelasnya, kemampuan akhir subjek dalam belajar IPS digambarkan dalam histogram berikut ini.

\section{Gambar 5}

Histogram Kategorisasi Skor Post-Test Hasil Belajar IPS Kelompok Eksperimen

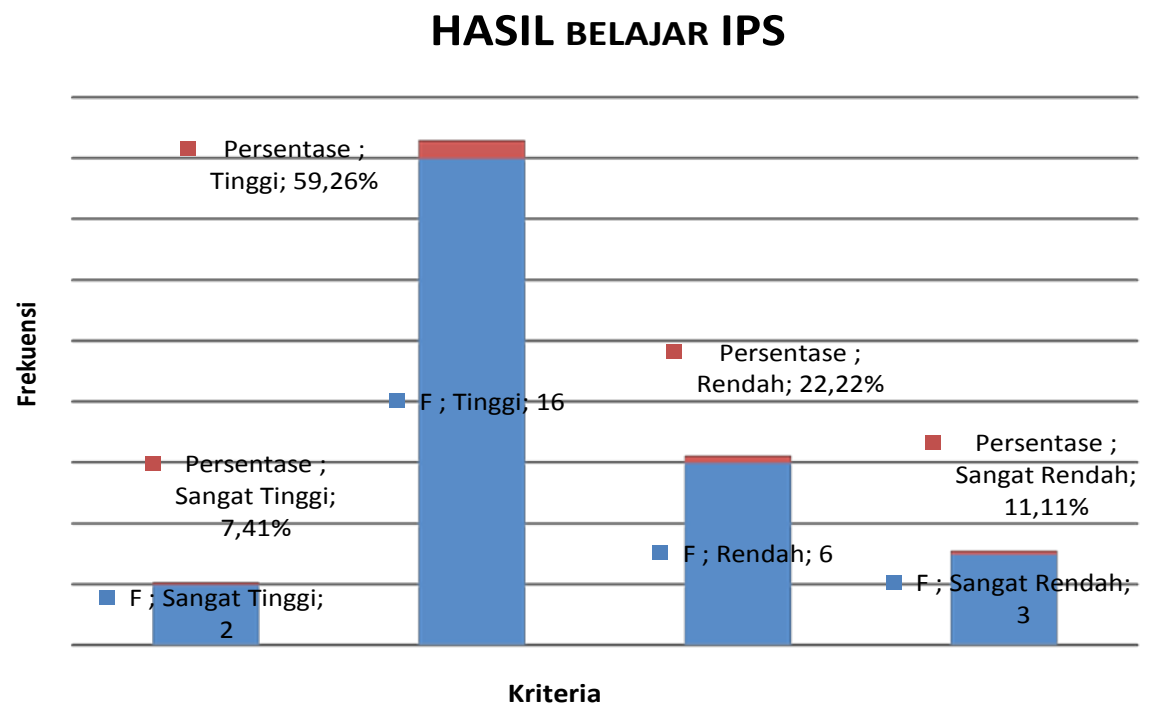

2) Nilai Kejujuran

Berdasarkan hasil statistik deskriptif dengan menggunakan SPSS16 for Windows, menunjukan bahwa skor akhir rata-rata kejujuran siswa kelompok eksperimen yaitu 100,37, standar deviasi 6,558, dengan skor tertinggi yaitu 114 dan skor terendah yaitu 87.

Berdasarkan kategorisasi memperlihatkan bahwa tingkat kejujuran subjek kelompok eksperimen yang sangat tinggi sebesar $18,52 \%$ atau sebanyak 5 siswa, yang termasuk dalam kategori tinggi sebesar 25,93\% atau sebanyak 7 siswa, yang termasuk dalam kategori rendah sebesar $44,44 \%$ atau sebanyak 12 siswa, dan yang termasuk dalam kategori sangat rendah sebesar $11,11 \%$ atau sebanyak 3 siswa. Hasil tersebut menunjukan bahwa secara umum tingkat kejujuran subjek kelompok eksperimen termasuk dalam kategori rendah dan tinggi. Kategori dan persentase kejujuran subjek kelompok eksperimen berdasarkan kategorisasi secara lengkap dapat dilihat dalam tabel 1 di bawah ini. 
Tabel 1

Distribusi Frekuensi Kategorisasi Skor Angket Nilai Kejujuran Kelompok Eksperimen

\begin{tabular}{cccccc}
\hline No. & Skor & Frekuensi & Persentase & $\begin{array}{c}\text { Cumulative Per- } \\
\text { cent }\end{array}$ & Kategori \\
\hline 1 & $84-75$ & 5 & $18,52 \%$ & $18,52 \%$ & Sangat Tinggi \\
2 & $74-70$ & 7 & $25,93 \%$ & $44,44 \%$ & Tinggi \\
3 & $69-66$ & 12 & $44,44 \%$ & $88,89 \%$ & Rendah \\
4 & $65-60$ & 3 & $11,11 \%$ & $100,00 \%$ & Sangat Rendah \\
\hline
\end{tabular}

Untuk lebih jelasnya, tingkat kejujuran subjek digambarkan dalam histogram berikut ini.

\section{Gambar 6 \\ Histogram Kategorisasi Tingkat Kejujuran Kelompok Eksperimen}

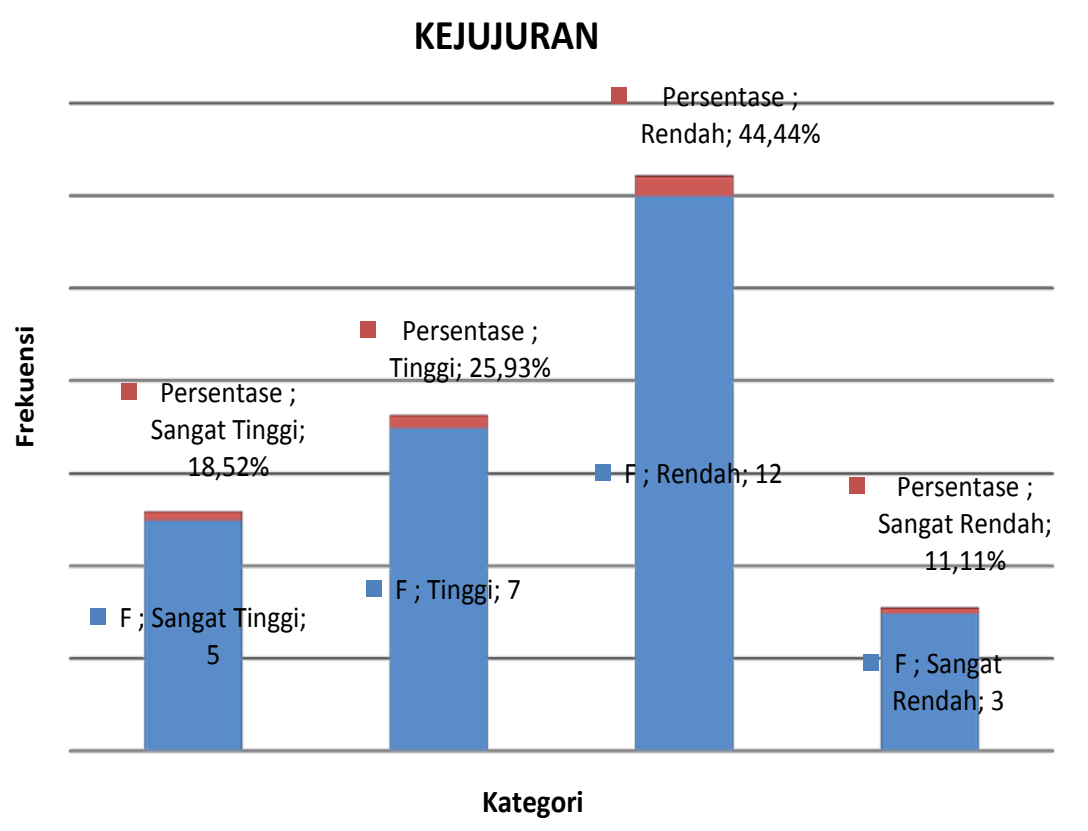

a. Deskripsi Data Post-Test Kelompok Kontrol

1) Hasil Belajar IPS

Berdasarkan hasil statistik deskriptif dengan menggunakan SPSS 16 for Windows, menunjukan bahwa skor akhir rata-rata hasil belajar IPS subjek kelompok kontrol yaitu 61,63, standar deviasi 6,564, dengan skor tertinggi yaitu 78 dan skor terendah yaitu 52 .

Berdasarkan kategorisasi dihasilkan bahwa kemampuan akhir subjek dalam belajar IPS yang sangat tinggi sebesar $22,22 \%$ atau sebanyak 6 siswa, yang termasuk dalam kate gori tinggi sebesar $18,52 \%$ atau sebanyak 5 siswa, yang termasuk dalam kategori rendah sebesar 33,33\% atau sebanyak 9 siswa, dan yang termasuk dalam kategori sangat rendah sebesar 25,93\% atau sebanyak 7 siswa. Hasil tersebut menunjukan bahwa secara umum kemampuan akhir siswa dalam belajar IPS dalam kategori tinggi. Kategori dan persentase akhir hasil belajar IPS siswa berdasarkan kategorisasi dapat dilihat dalam tabel di bawah ini. 
Tabel 2

Distribusi Frekuensi Kategorisasi Skor Post-Test Hasil Belajar IPS Kelompok Kontrol

\begin{tabular}{lrllll}
\hline No. & Skor & Frekuensi & Persentase & $\begin{array}{c}\text { Cumulative } \\
\text { Percent }\end{array}$ & \multicolumn{1}{c}{ Kategori } \\
\hline 1 & $78-68$ & 6 & $22,22 \%$ & $22,22 \%$ & Sangat Tinggi \\
2 & $67-62$ & 5 & $18,52 \%$ & $40,74 \%$ & Tinggi \\
3 & $61-57$ & 9 & $33,33 \%$ & $74,07 \%$ & Rendah \\
4 & $56-52$ & 7 & $25,93 \%$ & $100,00 \%$ & Sangat Rendah \\
\hline
\end{tabular}

Untuk lebih jelasnya, kemampuan akhir subjek dalam belajar IPS digambarkan dalam histogram berikut ini.

\section{Gambar 7}

Histogram Kategorisasi Skor Post-Test Hasil Belajar IPS Kelompok Kontrol

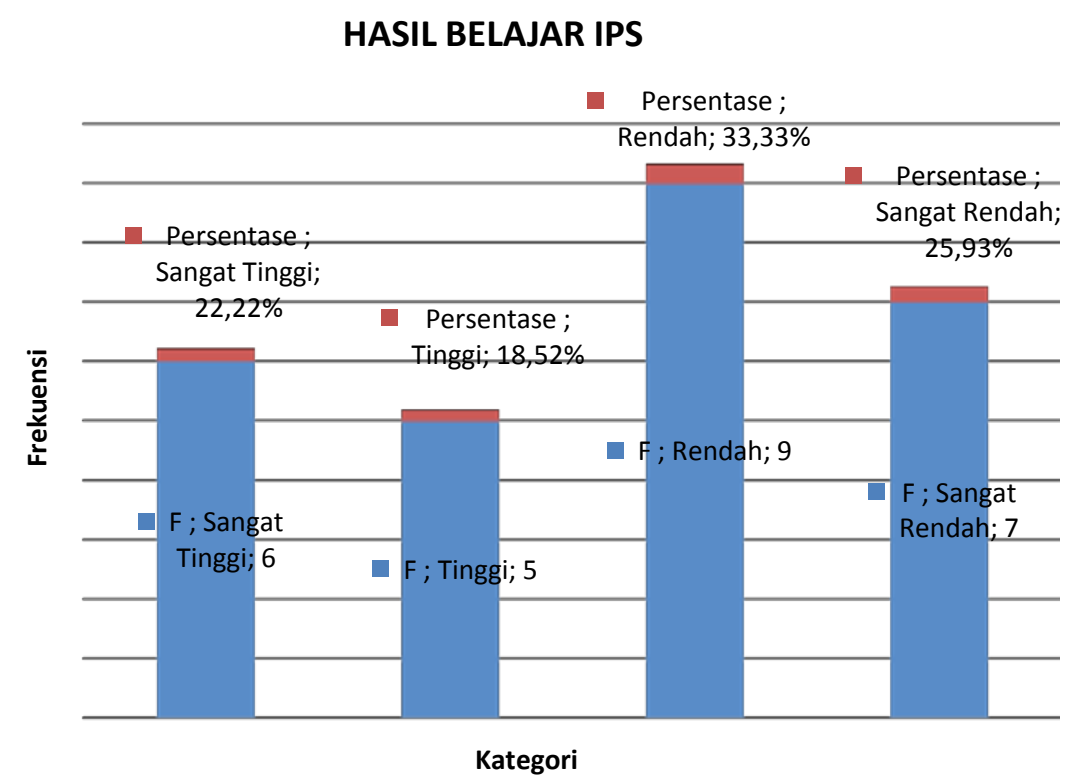

2) Nilai Kejujuran

Berdasarkan hasil statistik deskriptif dengan menggunakan SPSS 16 for Windows, menunjukan bahwa skor akhir rata-rata tingkat kejujuran subjek kelompok kontrol yaitu 89,41, standar deviasi 4,925, dengan skor tertinggi yaitu 100 dan skor terendah yaitu 80 .

Berdasarkan kategorisasi memperlihatkan bahwa tingkat kejujuran subjek yang sangat tinggi sebesar $18,52 \%$ atau seban- yak 5 siswa, yang termasuk dalam kategori tinggi sebesar $37,04 \%$ atau sebanyak 10 siswa, yang termasuk dalam kategori rendah sebesar 29,63\% atau sebanyak 8 siswa, dan yang termasuk dalam kategori sangat rendah sebesar $14,81 \%$ atau sebanyak 4 siswa. Hasil tersebut menunjukan bahwa secara umum tingkat kejujuran subjek dalam kategori tinggi. Kategori dan persentase tingkat kejujuran subjek berdasarkan kategorisasi dapat dilihat dalam tabel di bawah ini. 
Tabel 3.

Distribusi Frekuensi Kategorisasi Skor Angket Nilai Kejujuran Kelompok Kontrol

\begin{tabular}{llllll}
\hline No. & Skor & Frekuensi & Persentase & $\begin{array}{c}\text { Cumulative } \\
\text { Percent }\end{array}$ & \multicolumn{1}{c}{ Kategori } \\
\hline 1 & $100-94$ & 5 & $18,52 \%$ & $18,52 \%$ & Sangat Tinggi \\
2 & $93-89$ & 10 & $37,04 \%$ & $55,56 \%$ & Tinggi \\
3 & $88-85$ & 8 & $29,63 \%$ & $85,19 \%$ & Rendah \\
4 & $84-80$ & 4 & $14,81 \%$ & $100,00 \%$ & Sangat Rendah \\
\hline
\end{tabular}

Untuk lebih jelasnya, tingkat kejujuran subjek digambarkan dalam histogram berikut ini.

\section{Gambar 9 \\ Histogram Kategorisasi Tingkat Kejujuran Kelompok Kontrol}

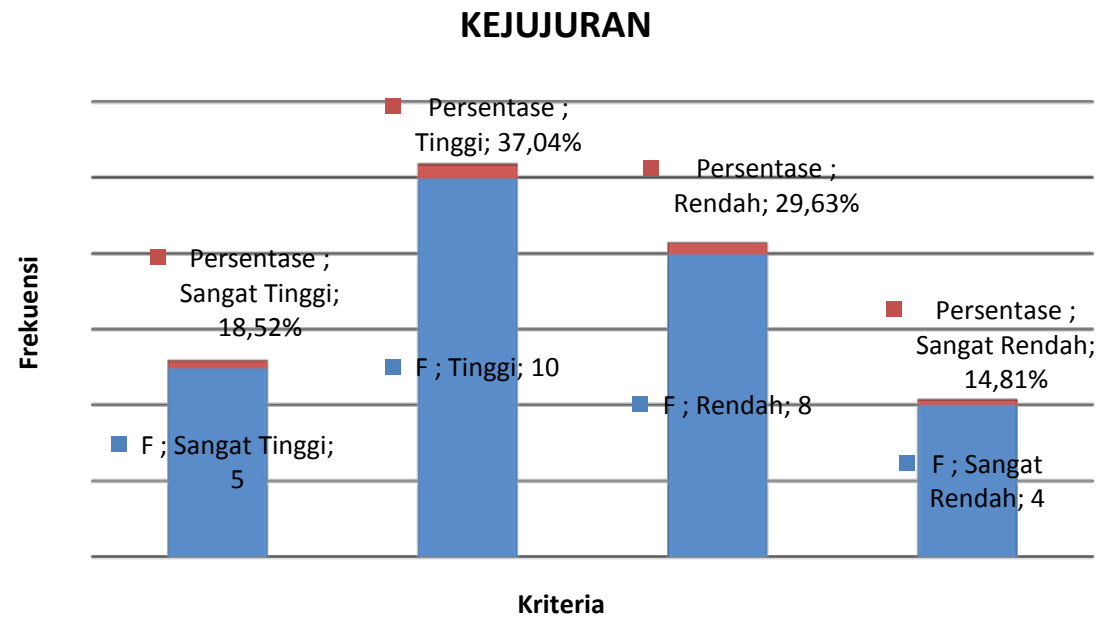

\section{Deskripsi Data Hasil Pengamatan}

Setelah diadakan pengamatan melalui lembar observasi indikator nilai kejujuran dalam pembelajaran IPS. Berikut akan disajikan data hasil pengamatan prilaku siswa saat proses pembelajaran maupun di luar proses pembelajaran dari pertemuan pertama sampai pertemuan kesepuluh, berikut hasil pe ngamatan prilaku siswa tersaji dalam tabel : 
Tabel 4.

Data Prilaku Siswa Kelompok Eksperimen dan Kelompok Kontrol

\begin{tabular}{lcrcc}
\hline \multirow{2}{*}{ No. } & Kelompok & Positif & Netral & Negatif \\
\hline 1. & Eksperimen & $57,31 \%$ & $25,41 \%$ & $17,11 \%$ \\
2. & Kontrol & $23,10 \%$ & $45,33 \%$ & $31,56 \%$ \\
\hline
\end{tabular}

Berdasarkan tabel 9 di atas jumlah siswa berprilaku jujur untuk kelompok eksperimen dalam kategori positif adalah sebanyak $57,31 \%$, sedangkan sebanyak $25,41 \%$ siswa menunjukan prilaku yang biasa-biasa saja atau netral, dan prilaku negatif ditunjukan sebanyak $17,11 \%$ siswa. Hal ini mengindikasikan bahwa prilaku jujur dalam kelompok eksperimen termasuk dalam kategori positif. Hasil pengamatan prilaku siswa untuk kelompok kontrol yaitu sebanyak $23,10 \%$ dalam kategori positif, sedangkan sebanyak 45,33\% siswa menunjukan prilaku yang biasa-biasa saja atau netral, dan prilaku negatif yang ditunjukan oleh siswa sebanyak 31,56\% siswa. Hal ini mengindikasikan bahwa prilaku jujur dalam kelompok kontrol secara umum termasuk dalam kategori netral atau biasa-biasa saja.

Hal ini menunjukan bahwa prilaku yang mencerminkan nilai kejujuran lebih banyak ditunjukan oleh siswa kelompok eksperimen dari pada kelompok kontrol. Hasil observasi prilaku siswa yang diamati pada saat proses pembelajaran maupun di luar proses pembelajaran menunjukan bahwa ada perbedaan prilaku jujur yang ditunjukan oleh siswa antara kelompok eksperimen dengan kelompok kontrol. Prilaku jujur yang banyak ditunjukan oleh siswa yaitu seperti siswa terlambat masuk kelas dan mengatakan alasan yang sebenarnya, siswa ketika mau memakai barang temannya mereka meminta izin terlebih dahulu, ada beberapa siswa yang langsung mengaku ketika merusak barang temannya, kasus mencontek ketika ulangan juga lebih banyak terjadi di kelas kontrol.

Perilaku siswa yang dapat diamati secara langsung di luar proses pembelajaran adalah seperti membayar barang atau makanan yang dibeli, menambah atau mengurangi cerita kejadian yang sebenarnya. Kasus yang terjadi di sekolah adalah adanya temuan uang sebesar Rp. 20. 000 di depan perpustakaan. Ketika uang tersebut diumumkan di kelas eksperimen, tidak ada siswa yang mau me ngaku kepemilikan uang tersebut. Berbeda dengan di kelas kontrol, ketika di umumkan ada temuan uang ada beberapa siswa yang langsung mengaku kalau uang itu adalah uang mereka padahal uang yang mereka akui jumlanhnya tidak sesuai.

\section{Deskripsi Peningkatan Skor Hasil Bela- jar IPS dan Tingkat Kejujuran}

Data peningkatan skor belajar berupa hasil belajar IPS dan nilai kejujuran. Data tersebut diperoleh berdasarkan pada skor pre-test dan post-test pada kelompok eksperimen kemudian dibandingkan dengan peningkatan skor pada kelompok kontrol. Di bawah ini akan diuraikan data peningkatan skor hasil belajar IPS dan tingkat kejujuran siswa.

Peningkatan hasil belajar IPS dan nilai kejujuran diperoleh dengan cara mencari selisih antara dua tes yang sudah dilakukan yaitu selisih skor pre-test dan skor post-test baik pada kelompok eksperimen maupun pada kelompok kontrol. Data tersebut diambil dengan maksud untuk mengetahui perbedaan peningkatan hasil belajar IPS dan nilai kejujuran antara kelompok eksperimen dengan kelompok kontrol. Data selisih antara pre-test dengan post-test kedua kelompok tersebut terangkum dalam tabel di bawah ini. 
Tabel 5

Peningkatan Skor Hasil Belajar IPS dan Kejujuran

\begin{tabular}{ccccccc}
\hline \multirow{2}{*}{ Kelompok } & \multicolumn{3}{c}{ Peningkatan Hasil Belajar IPS } & \multicolumn{3}{c}{ Peningkatan Kejujuran } \\
\cline { 2 - 7 } & Skor & $\%$ & S. D & Skor & $\%$ & S. D \\
\hline Eksperimen & 15,41 & $57,07 \%$ & 6,968 & 16,74 & $62,00 \%$ & 5,346 \\
Kontrol & 4,96 & $18,37 \%$ & 6,711 & 3,78 & $14,00 \%$ & 3,866 \\
\hline
\end{tabular}

Berdasarkan tabel 10 di atas, tampak bahwa ada peningkatan yang cukup tinggi pada kelompok eksperimen dibandingkan dengan peningkatan yang terjadi pada kelompok kontrol. Hal ini bisa di lihat bahwa pada kelompok eksperimen, skor rerata hasil belajar IPS mengalami kenaikan sebesar 15,41 atau 57,07\% dan SD 5,346, sedangkan pada kelompok kontrol, skor hasil belajar IPS mengalami peningkatan sebesar 4,96 atau $18,37 \%$ dan SD 3,866.

Dari tabel 10 di atas juga terlihat bahwa skor total kenaikan nilai kejujuran siswa pada kelompok eksperimen yaitu sebesar
16,74 atau $(62,00 \%)$, sedangkan pada kelompok kontrol skor kenaikan nilai kejujuran siswa yaitu sebesar 3,78 (14,00\%). Dengan demikian, dari perbandingan peningkatan skor nilai kejujuran siswa antara kelompok eksperimen dengan kelompok kontrol dapat dinyatakan bahwa peningkatan skor nilai kejujuran siswa pada kelompok eksperimen lebih tinggi dari kelompok kontrol. Untuk lebih jelasnya hasil penghitungan statistik mengenai perbandingan peningkatan hasil belajar yang berupa hasil belajar IPS dan nilai kejujuran pada kedua kelompok tersebut tergambar seperti pada histogram berikut ini.

\section{Gambar 10. \\ Peningkatan Hasil Belajar IPS dan Nilai Kejujuran}

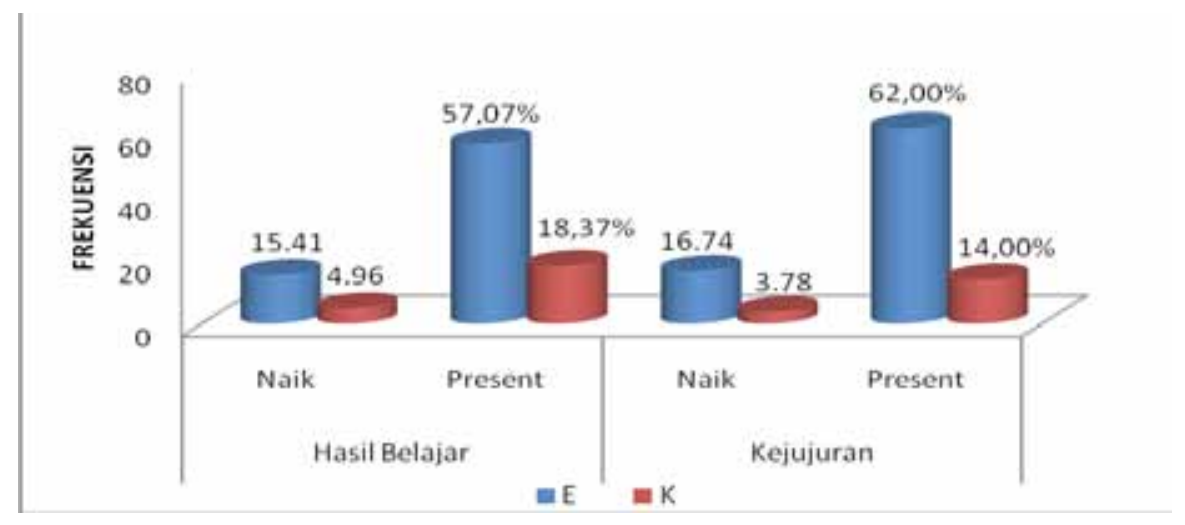

Dari gambar di atas jelas bahwa peningkatan hasil belajar pada kelompok eksperimen dengan penggunaan metode Cooperative Learning tipe STAD dalam pembelajaran IPS lebih tinggi dibandingkan dengan peningkatan pada kelompok kontrol yang mengguna kan metode konvensional. Dengan demikian dapat dinyatakan bahwa metode Cooperative Learning tipe STAD yang diterapkan dalam pembelajaran IPS di 
SMP lebih efektif untuk meningkatkan hasil belajar IPS dan nilai kejujuran siswa. Dari data yang sudah disajikan baik dalam bentuk data maupun histogram di atas, dapat dinyatakan bahwa penggunaan metode Cooperative Learning tipe STAD dalam pembelajaran IPS efektif untuk meningkatkan kejujuran siswa.

\section{UJI HIPOTESIS PENELITIAN}

\section{a. Pengujian Hipotesis Pertama}

Hipotesis pertama yang akan diuji dalam penelitian ini adalah terdapat perbedaan pe ningkatan hasil belajar IPS antara siswa yang menggunakan metode Cooperative Learning tipe STAD dengan siswa yang tidak menggunakan metode Cooperative Learning tipe $S T A D$. Sedangkan hipotesis penelitian $\left(\mathrm{H}_{\mathrm{a}}\right)$ menyatakan bahwa terdapat perbedaan pe ningkatan hasil belajar IPS antara siswa yang menggunakan metode Cooperative Learning tipe STAD dengan siswa yang menggunakan metode pembelajaran konvensional.

Hasil analisis data menunjukan bahwa hasil belajar IPS siswa setelah diberi perlakuan dengan menggunakan metode pembelajaran yang berbeda mengalami peningkatan. Besar perubahan atau peningkatan hasil belajar IPS yang terjadi pada kelompok eksperimen adalah sebesar 15,41 atau 57,07\% dengan SD 6,968 dan pada kelompok kontrol sebesar 4,96 atau $18,37 \%$ dengan SD 6,711. Keduanya berbeda signifikan $(p<0.05)$ dengan terhitung 5,610 dan probabilitas sebesar 0,000.

Dengan demikian dapat dijelaskan bahwa terjadi perbedaan peningkatan hasil belajar IPS antara kelompok yang proses pembelajarannya menggunakan metode Cooperative Learning tipe STAD dibandingkan kelompok yang proses pembelajarannya menggunakan metode konvensional. Peningkatan yang terjadi pada kelompok eksperimen lebih tinggi dibandingkan dengan peningkatan yang terjadi pada kelompok kontrol.

Berdasarkan hasil pengujian hipotesis pertama ini dengan menggunakan uji-t dapat dinyatakan bahwa ada perbedaan peningkatan yang siginifikan pada hasil belajar IPS.
Hal ini terbukti bahwa harga t-hitung sebesar $5,610(p=0,000)$. Oleh karena $p<0,05$, maka hipotesis nihil ditolak atau hipotesis penelitian diterima. Hal ini berarti bahwa metode Cooperative Learning tipe STAD efektif untuk meningkatkan hasil belajar IPS siswa SMP.

\section{b. Pengujian Hipotesis Kedua}

Hipotesis kedua yang akan diuji dalam penelitian ini adalah hipotesis nihil $\left(\mathrm{H}_{0}\right)$ yang menyatakan bahwa tidak terdapat perbedaan peningkatan nilai karakter siswa SMP yaitu nilai kejujuran melalui pembelajaran IPS yang menggunakan metode Cooperative Learning tipe STAD dibandingkan dengan yang menggunakan metode pembelajaran konvensional. Sedangkan hipotesis penelitian $\left(\mathrm{H}_{\mathrm{a}}\right)$ menyatakan bahwa terdapat perbedaan peningkatan nilai karakter siswa SMP yaitu nilai kejujuran melalui pembelajaran IPS yang menggunakan metode Cooperative Learning tipe STAD dibandingkan dengan yang menggunakan metode pembelajaran konvensional.

Hasil anaisis data dengan Uji-t menunjukan bahwa nilai kejujuran siswa setelah diberi perlakuan dengan menggunakan metode pembelajaran yang berbeda me ngalami peningkatan. Besar perubahan atau peningkatan nilai kejujuran siswa yang terjadi pada kelompok eksperimen adalah sebesar 16,74 atau $62,00 \%$ dengan SD 5,346, dan pada kelompok kontrol sebesar 3,78 atau $14,00 \%$ dengan SD 3,866. Keduanya berbeda signifikan $(\mathrm{p}<0.05)$ dengan t-hitung 10,209 dan probabilitas sebesar 0,000 .

Dengan demikian dapat dijelaskan bahwa terjadi perbedaan peningkatan nilai kejujuran siswa antara kelompok yang proses pembelajarannya menggunakan metode Cooperative Learning tipe STAD dibandingkan kelompok yang proses pembelajarannya menggunakan metode konvensional. Berdasarkan hasil pengujian hipotesis dengan menggunakan Uji-t, pada hipotesis kedua ini dapat dinyatakan bahwa ada perbedaan siginifikan pada peningkatan nilai karakter siswa SMP yaitu nilai kejujuran melalui pem- 
belajaran IPS yang menggunakan metode $\mathrm{Co}$ operative Learning tipe STAD dibandingkan dengan yang menggunakan metode pembelajaran konvensional. Hal ini dapat dibuktikan dengan mempertimbangkan harga t-hitung sebesar 10,209 $(p=0,000)$. Oleh karena $\mathrm{p}<0,05$, maka hipotesis nihil ditolak atau hipotesis penelitian diterima. Hal ini berarti bahwa metode Cooperative Learning tipe STAD efektif untuk meningkatkan karakter siswa SMP yaitu nilai kejujuran pada kelompok eksperimen.

\section{SIMPULAN}

Berdasarkan hasil penelitian dan pembahasan pada bab IV, maka dapat diambil beberapa simpulan sebagai berikut:

1. Metode Cooperative learning tipe STAD lebih efektif untuk meningkatkan hasil belajar IPS siswa, dibandingkan dengan metode pembelajaran secara konvensional (t-hitung 5,610 dan $\mathrm{p}=0,000<$ $0,05)$.

2. Metode Cooperative learning tipe STAD lebih efektif untuk meningkatkan karakter siswa yaitu nilai kejujuran, dibandingkan dengan menggunakan metode pembelajaran secara konvensional (t-hitung = 10,209 dan $p=0,000<0,05$ ).

\section{DAFTAR PUSTAKA}

Hasan, Said Hamid dkk. 2010. Pengembangan pendidikan budaya dan karakter bangsa. Jakarta: Badan Penelitian dan Pengembangan Pusat Kurikulum.

Isjoni. 2007. Integrated Learning (Pendekatan Pembelajaran IPS di Pendidikan Dasar). Pekanbaru: Falah Production.

Lickona, Thomas. 1991. Educating for Character. How Our School Can Teach Respect and Responsibility. New York: Bantam Books.

Marzuki. 2009. Prinsip Dasar Akhlak Mulia: Pengantar Studi Konsep-Konsep Dasar Etika dalam Islam. Yogyakarta: Debut Wahana Press.

R. E. , Slavin. 1995. Cooperative learning: Theory research and practice $\left(2^{n}\right.$ ed). Boston: Allymand \& Bacon.

Soewarso. 1998. "Menggunakan Strategi Komparatif Learning Di Dalam Pendidikan Ilmu Pengetahuan Sosial : Edukasi", hlm 16-25.

Solihatin, Etin dan Raharjo. 2008. Cooperative Learning: Analisis Model Pembelajaran IPS. Jakarta: Bumi Aksara.

T. V, Savage dan D. G Amstrong. 1996. Effective teaching in elementary social studies (third edition). New Jersey: Prentice Hall. 